\title{
Pengembangan Ketersediaan Informasi Akademik Sekolah Menengah Atas DKI Jakarta Berbasis Web
}

\author{
Rudi Prasetya ${ }^{1}$, Heri Satria Setiawan ${ }^{2}$ \\ 1,2)Informatika,FTIK,Universitas Indraprasta \\ Jl. Raya Tengah No.80 C Jakarta \\ Email: rudiprasetya1@gmail.com, heri.satria71@yahoo.com
}

\begin{abstract}
ABSTRAK
Sekolah yang ada di Jakarta dalam pengolahan seluruh data dan kebutuhan ketersediaan informasi baik untuk kebutuhan internal maupun eksternal sampai saat ini masih dilakukan secara manual, sehingga kinerja sistem administrasi dan yang lainnya belum otimal., pada hal kemajuan industri dan perusahaan bisnis menuntut penataan seluruh sistem yang cermat, cepat, dan canggih, kebutuhan ini dapat dipenuhi dengan baik jika tersedia informasi yang lengkap dan akurat dalam berbagai sumber informasi yang terpecaya yaitu salah satunya dengan cara sistem komputerisasi dalam kegiatan tersebut. Untuk mengatasi permasalahan yang dihadapi oleh sehingga kebutuhan layanan informasi bagi manajemen maupun pengguna informasi lainnya dapat diperoleh secara optimal maka penulis mengusulkan Pengembangan Ketersediaan Informasi Akademik Berbasis Web pada Sekolah Menengah Atas di DKI Jakarta yang Berbasis Web yang meliputi laporan raport nilai siswa, pengelolahan data nilai, penjadwalan mata pelajaran dan lain sebagainya yang diolah menjadi lebih cepat dan tepat waktu, akurat, penghematan ruang penyimpanan data (memori) dan mengurangi penumpukan arsip yang tidak perlu, selain itu ada satu keunggulan lain yang tidak kalah penting yaitu bentuk laporan data yang memiliki tingkat kualitas yang tinggi, hal ini disebabkan karena komputer dapat memberikan hasil cetakan yang lebih baik. Dengan sistem ini diharapkan juga kinerja staff dan karyawan Sekolah DKI Jakarta menjadi lebih baik dan dapat memberikan pelayanan yang terbaik kepada siswa.
\end{abstract}

Kata kunci: Ketersediaan Informasi Akademik, Informasi Akademik, Sekolah, Web.

\begin{abstract}
Schools in Jakarta in the processing of all data and the need for information availability both for internal and external needs are still done manually, so that the performance of the administrative system and others is not yet optimal, in terms of industrial progress and business companies demanding structuring the entire system careful, fast, and sophisticated, these needs can be met properly if complete and accurate information is available in a variety of trusted sources of information, one of which is by means of a computerized system in the activity. To overcome the problems faced by the information service needs for management and other users of information can be obtained optimally, the authors propose the Development of Web-Based Academic Information Availability in Web-Based High Schools in DKI Jakarta which includes student grades report cards, management of value data, subject scheduling and others that are processed to be faster and timely, accurate, saving data storage space (memory) and reducing unnecessary archive buildup, besides that there is one other advantage that is not less important, the form of data reporting that has a quality level high, this is because the computer can provide better prints. With this system it is expected that the performance of staff and employees of DKI Jakarta School will be better and be able to provide the best service to students.
\end{abstract}

Keywords: Availability of Academic Information, Academic Information, School, Web

\section{Pendahuluan}

Ketersedian informasi dalam melayani informasi pendidikan sangatlah penting karena kebutuhan tersebut merupakan tuntutan teknologi informasi yang menyediakan informasi yang cepat, efisien terhadap mencari informasi, dan mudah digunakan di tengah masyarakat khususnya di pendidikan Sekolah Menengah Atas di DKI Jakarta. Web merupakan teknologi yang tepat di sekolah memberikan pelayanan informasi yang baik terhadap masyarakat di DKI jakarta Informasi kegiatan akademik, akan mudah diakses oleh guru, karyawan dan murid masyarakat maupun stakeholder lain yang berguna untuk mendukung dalam rangka keterbukaan program pendidikan di sekolah menengah atas. 
Berdasarkan uraian di atas bahwa sistem informasi akademik berbasis web di DKI Jakarta sangat diperlukan dalam dunia pendidikan khususnya pemberian informasi akademik, sehingga membantu kecepatan dan kualitas dalam penyampaian informasi. Selain itu dengan berbasiskan web maka informasi data dapat di akses dengan waktu dan tempat yang tidak ditentukan.

\section{MetodePenelitian}

\subsection{Analisa Penelitian}

Menganalisa pada penelitian ini merupakan langkah awal yang harus dilakukan, meliputi :

a. Planning, Dalam tahapan ini penulis melakukan pengumpulan informasi yang akan dibuat, dengan cara mengumpulkan hasil sistem apa yang akan dibuat pada sistem di Sekolah Menengah Atas DKI Jakarta

b. Analisis, Pada tahapan ini penulis membagi dua tahapan analisa yaitu analisa teknologi dan analisa informasi. Analisa teknologi adalah penulis menentukan teknologi apa yang akan digunakan seperti pemilihan desain web. Yang menggunakan Adobe Photoshop 7.0, Macromedia Dreamweaver 8. Penulis juga menentukan data penyimpanan database informasi sekolah dengan menggunakan Mysql. Selanjutnya tahap analisa informasi, pada tahap ini penulis membagi menjadi dua buah informasi data yaitu data tetap dan data dinamis. Kategori data tetap adalah sejarah, profile, dan visi misi sekolah sedangkan data dinamis adalah beberapa informasi yang selalu berubah dalam setiap periodik. Informasi data dinamis dalam sistem ini adalah seperti informasi siswa, guru dan karyawan sekolah, data siswa, data guru karyawan, data nilai siswa, data alumni, serta katalog kegiatan sekolah.

c. Desain, Pada bagian ini penulis melakukan dua tahapan juga. Yaitu desain informasi dan desain grafis. Pada desain informasi penulis melakukan atau mendesain berupa halaman web dan men-set hyperlink serta struktur desain dari database dan proses dari data input dan data output. Selanjutnya penulis melakukan desain grafis diantaranya mendesain grafik dan kesesuaian warna layout (tampilan) berupa gambar dan animasi agar web terlihat menarik

d. Implementasi. Pada tahap ini dilakukan pengembangan sistem dengan mengimplementasikan desain ke dalam kode program yang diperlukan oleh sekolah SMA melalui database dan SQL, dan serangkaian tes program dan memasukkan data-data, apakah program tersebut sudah benar dan dapat digunakan sesuai dengan kebutuhan sekolah SMA

\subsection{Pengumpulan Data}

Metode pengumpulan data merupakan suatu cara yang digunakan untuk mendapatkan data atau informasi dari sistem yang dianalisa. Padapenelitian kali ini meliputi :

a. Observasi, Dalam aspek Observasi yaitu mempelajari perilaku organisasi salah satu sekolah di jakarta, proses kerja organisasi dan mempelajari karakterisitik lingkungan, setelah itu menyusun pokok yang di bahas sesuai dengan rencana pembuatan informasi akademik sekolah di ambil pada salah satu contoh sekolah SMA di Jakarta, kemudian di rekam melalui teks dan mendeskripsikan mengartikan alur pokok permasalahan yang didapat, mencari dan menambahkan data data berupa gambar dan angka berupa suatu parameter atau ukuran yang ada di sekolah tersebut, data yang di dapat berupa sejarah organisasi, struktur organsiasi, aktifitas kerja, komposisi system berjalan, spesifikasi dokumen masukan dan keluaran, dan masalah yang ada di organisasi.

b. Wawancara, Melakukan tatap muka terhadap actor atau sumber daya manusia yang secara langsung berkaitan dengan ke akademik dan lingkup system yang berlaku terhadap sekolah, yaitu kepala sekolah, guru, murid, orang tua wali murid.

c. Studi Pustaka. Mengumpulkan fakta-fakta dan data-data yang berkaitan dengan tema yang penulis pilih, antara lain berbagai referensi buku-buku, literature, web dan artikel

\subsection{Ruang Lingkup}

Meliputi: penyajian ketersediaan informasi kepada siswa mengenai data nilai harian, nilai tengah semester, nilai ujian akhir semester dan nilai ekstra kurikuler, data absensi serta menyajikan informasi kepada user mengenai daftar pegawai, daftar pengajar, daftar kelas serta daftar jadwal mata pelajaran. Aplikasi ini dibangun dengan menggunakan bahasa pemograman PHP dan Dreamweaver sebagai alat bantu dalam mendesain situs web, aplikasi basis data yang digunakan adalah MySql (phpMyAdmin). 


\section{Pembahasan}

Adapun hasil dari penelitian ini berupa usulan dan pembuatan aplikasi berbaasi web yang mempermudah ketersediaan informasi akademik di sekolah SMA DKI Jakarta.

\subsection{Dekomposisi Sistem Berjalan}

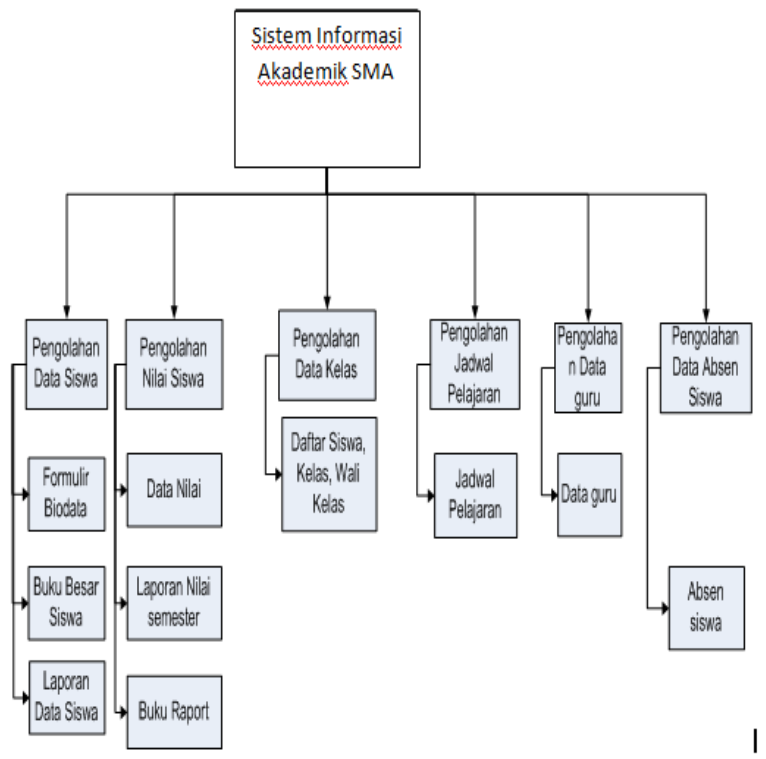

Gambar 1. Dekomposisi fungsi system berjalan

\subsection{Activity Diagram Berjalan pada Data Siswa}

Menurut Hariyanto (2004), Activity Diagram adalah diagram flowchart yang diperluas yang menunjukkan aliran kendali satu aktivitas ke aktivitas lain. Kita dapat menggunakan diagram ini untuk memodelkan aspek dinamis sistem.

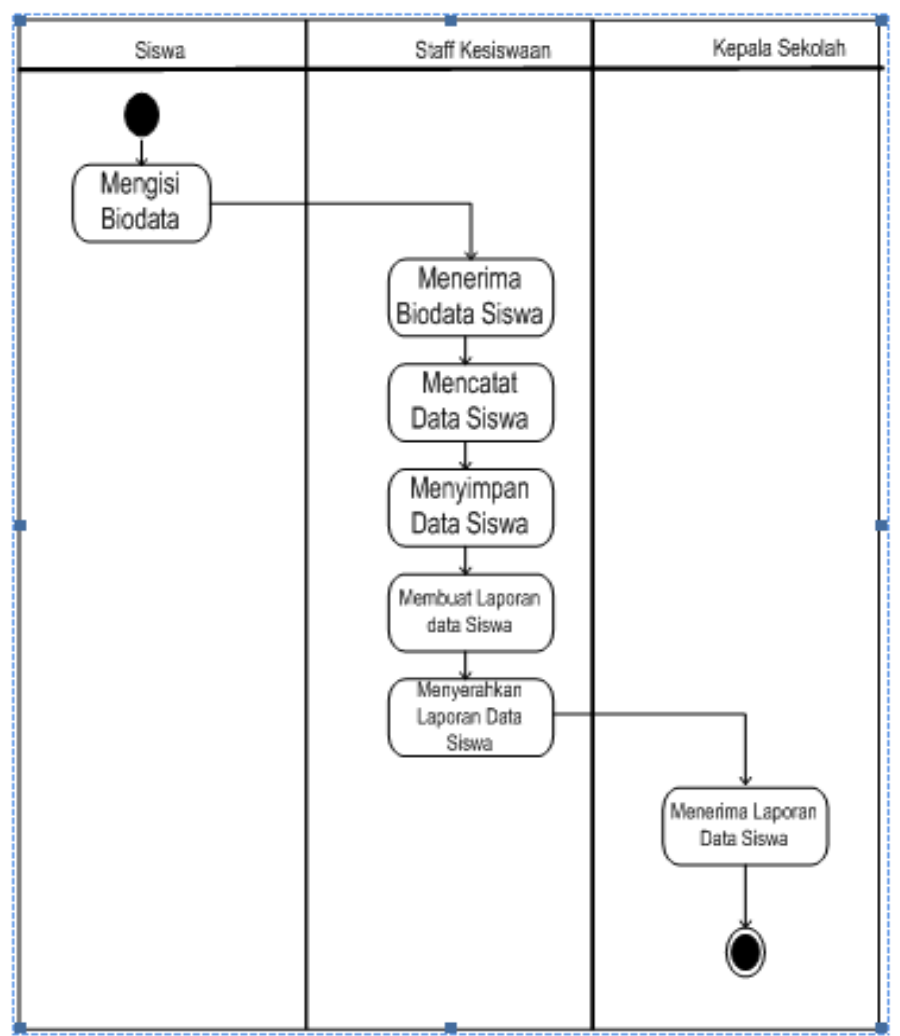

Gambar 2. Activity Diagram Berjalan pada Data Siswa 


\subsection{Permasalahan}

Dari hasil analsis sistem yang sedang berjalan dapat disimpulkan bahwa ada beberapa kekurangan yang perlu di kembangkan dari sistem, guna kemudahan dan efektifitas waktu. Adapun kekurannganya yaitu :

1. Kurang efektinya publikasi informasi akademik sekolah atau atau lainnya yang biasanya hanya di tempel dipapan pengumuman.

2. Belum adanya sistem informasi akademik secara terstruktur sekolah yang disajikan secara online.

3. Pengelolaan jadwal pelajaran dan data nilai masih menggunakan aplikasi perkantoran biasa yang sifatnya offline dan stand alone, menyebabkan informasi mengenai jadwal dan nilai relatif lebih lama diperoleh orang tua wali murid.

\subsection{Alternatif Permasalahan}

Berdasarkan permasalahan-permasalahan yang telah diuraikan tersebut, maka diperlukan suatu sistem informasi akademik berbasis web pada SMA DKI Jakarta sebagai media dalam menyampaikan informasi akademik secara lebih luas kepada masyarakat.

Oleh karena itu maka sekolah mencoba merubah dan memperbaharui sistem yang telah ada dengan membangun sistem informasi akademik berbasis web pada SMA di Jakarta dengan tujuan sebagai berikut :

1. Informasi akademik tentang sekolah yang berbasis website pada SMA Jakarta.

2. Membuat fasilitas jadwal pelajaran kelas, laporan status keuangan siswa dan nilai online yang memudahkan siswa untuk mengetahui informasi tersebut.

3. Membuat halaman penilaian yang memudahkan guru untuk memasukkan nilai hasil belajar siswa setiap satu semester.

4. Menyimpan data Siswa dan data Pegawai sekolah secara komputerisasi yang berbasis webiste

5. Membuat laporan raport, nilai, keuangan kepada kepala sekolah yang berbasis website

\section{Hasil Pengembangan Ketersediaan Informasi Akademik}

\subsection{Dekomposisi Fungsi Sistem Usulan}

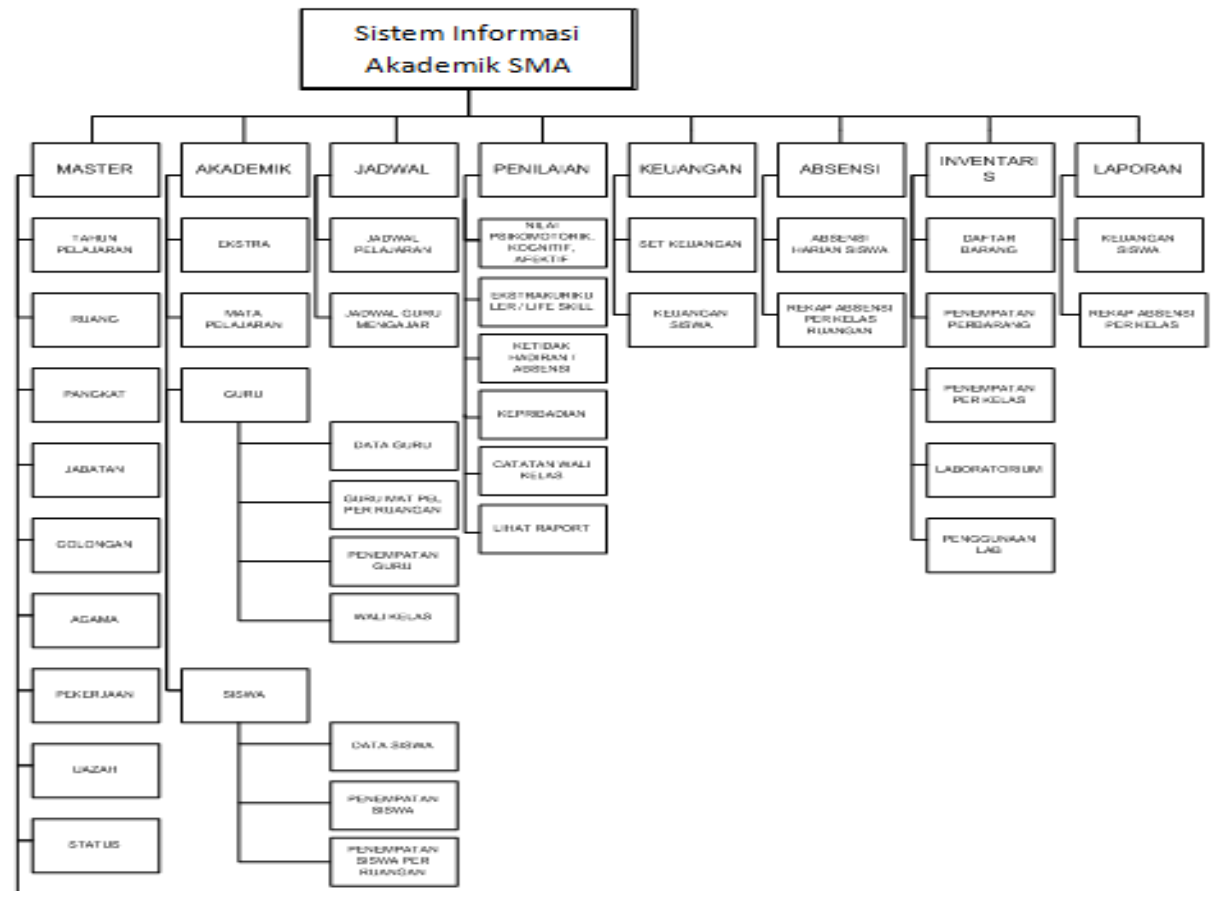

Gambar 4.1. Dekomposisi fungsi sistem usulan 


\subsection{Usecase Diagram Sistem Usulan}

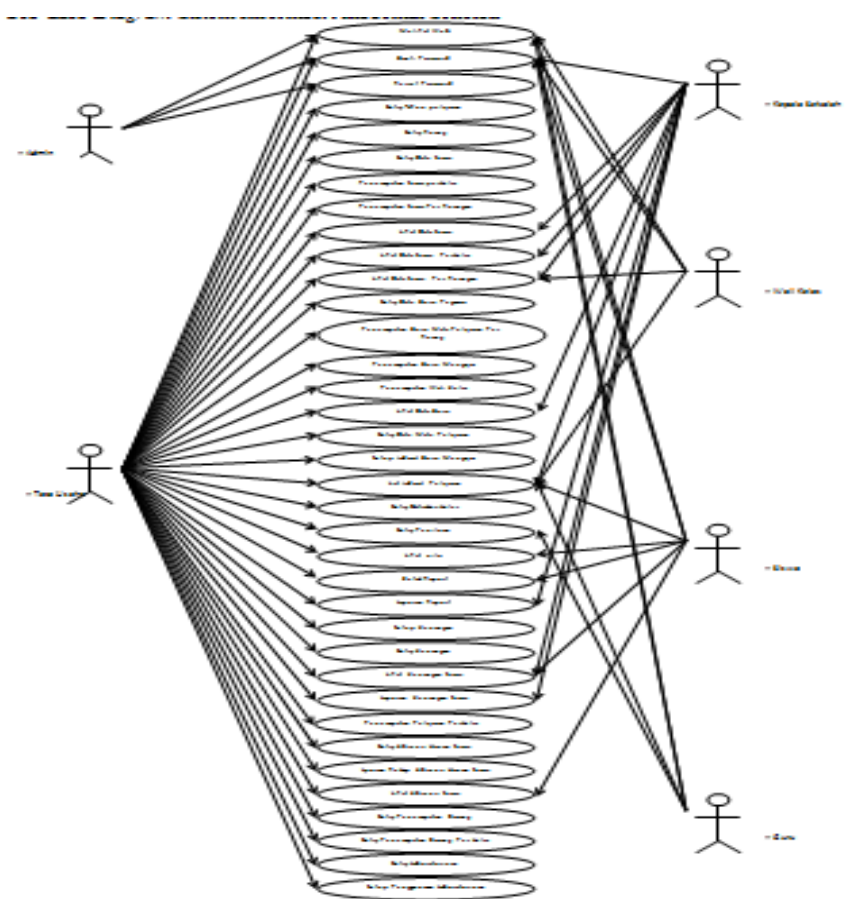

Gambar 4.2 Use Case Diagram web sekolah

\subsection{Component Diagram}

Komponen piranti lunak adalah modul berisi code, baik berisi source code maupun binary code, baik library maupun executable, baik yang muncul pada compile time, link time maupun run time.

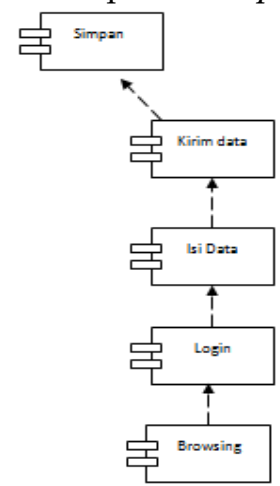

Gambar 4.3 Component diagram 


\subsection{ERD (Entity Relationship Diagram) Usulan}

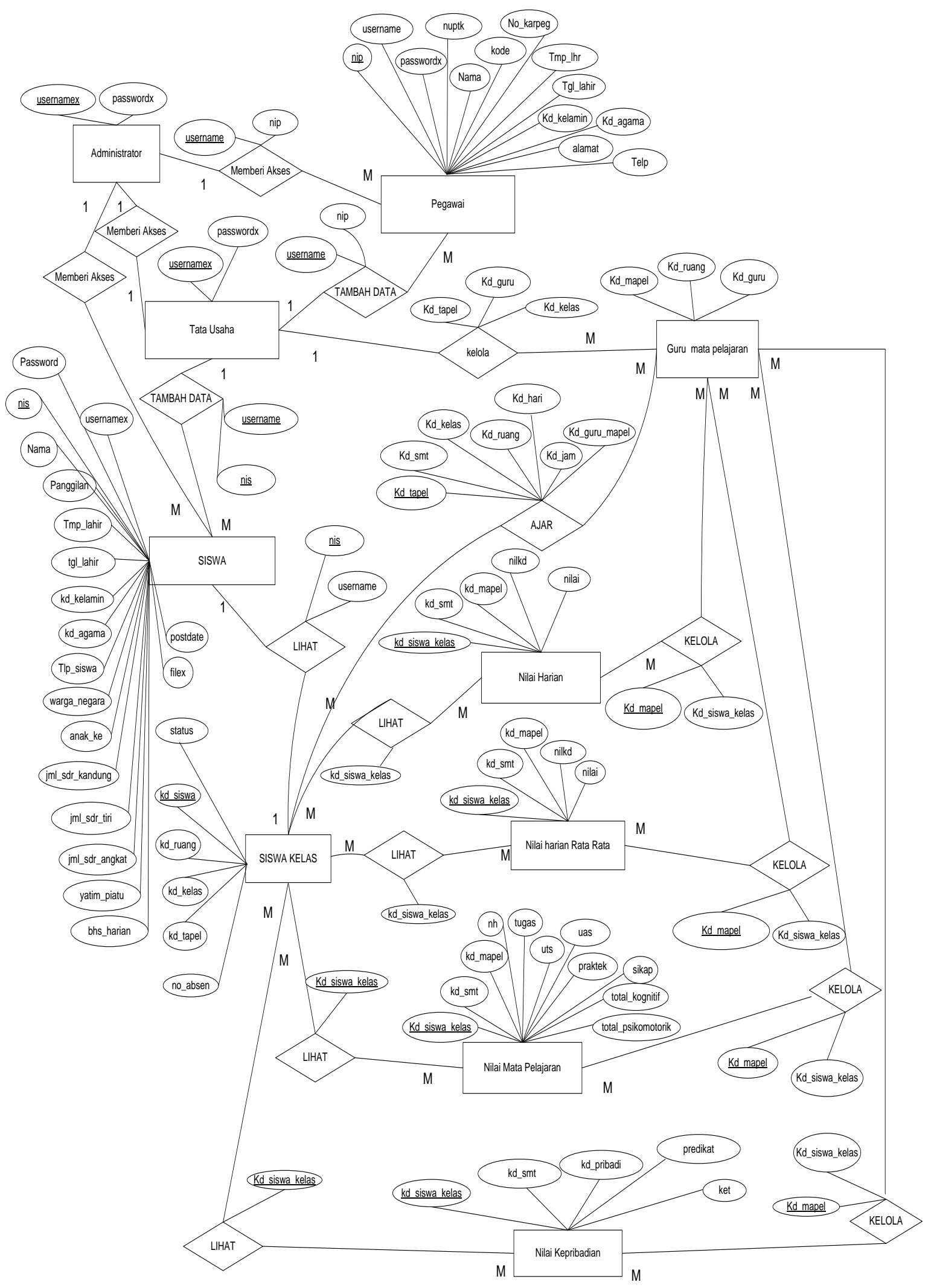

Gambar 4.4 ERD usulan 


\subsection{Tampilan Web}

Pada dasarnya tujuan pokok dibangunnya system informasia kademik berbasis web pada Sekolah Menengah Atas DKI Jakarta ini adalah untuk menunjang kelancaran dari proses belajar mengajar yang dilakukan di sekolah dibutuhkan sebuah system informasi akademik yang akurat tentang informasi akademik pendidikan dari sekolah kepada siswa, guru, kepala sekolah maupun pihak yang berkepentingan akan sebuah informasi akademik pada sekolah tersebut.

\section{SISTEM INFORMLSI AKADEMIK SMLA NEGERI 72 JAKARTA}

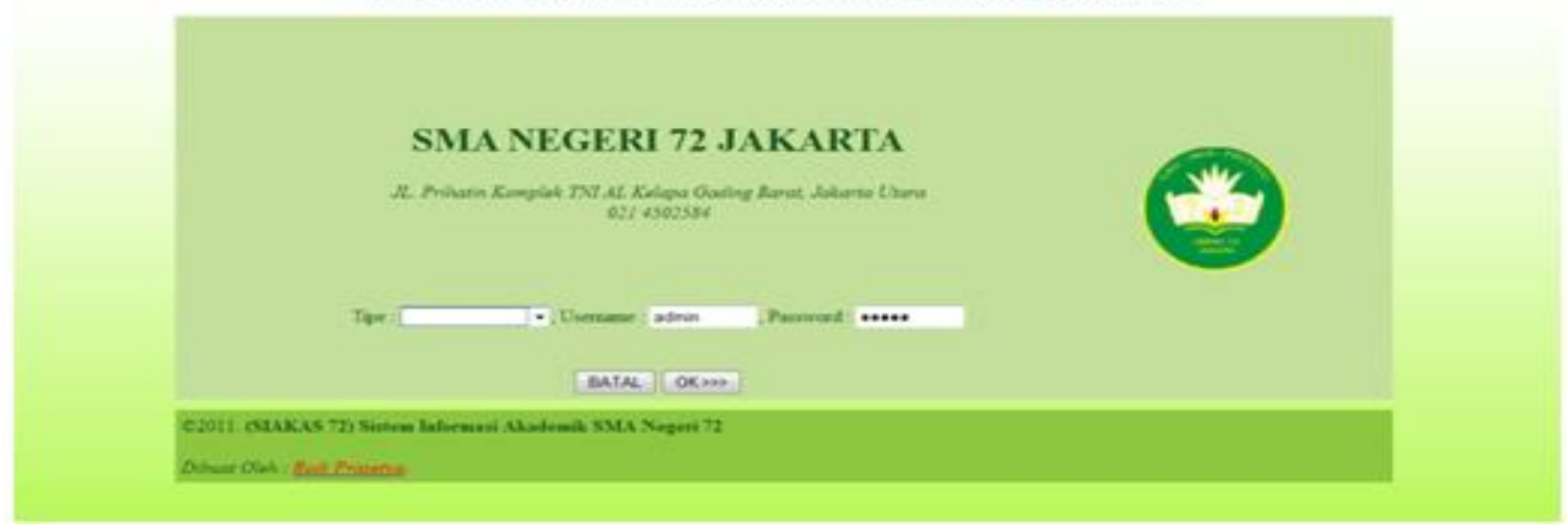

Gambar 4.5 Tampilan halaman muka

Halaman admtu/akad/siswa.php berisikan data siswa pada kelas rombongan belajar.

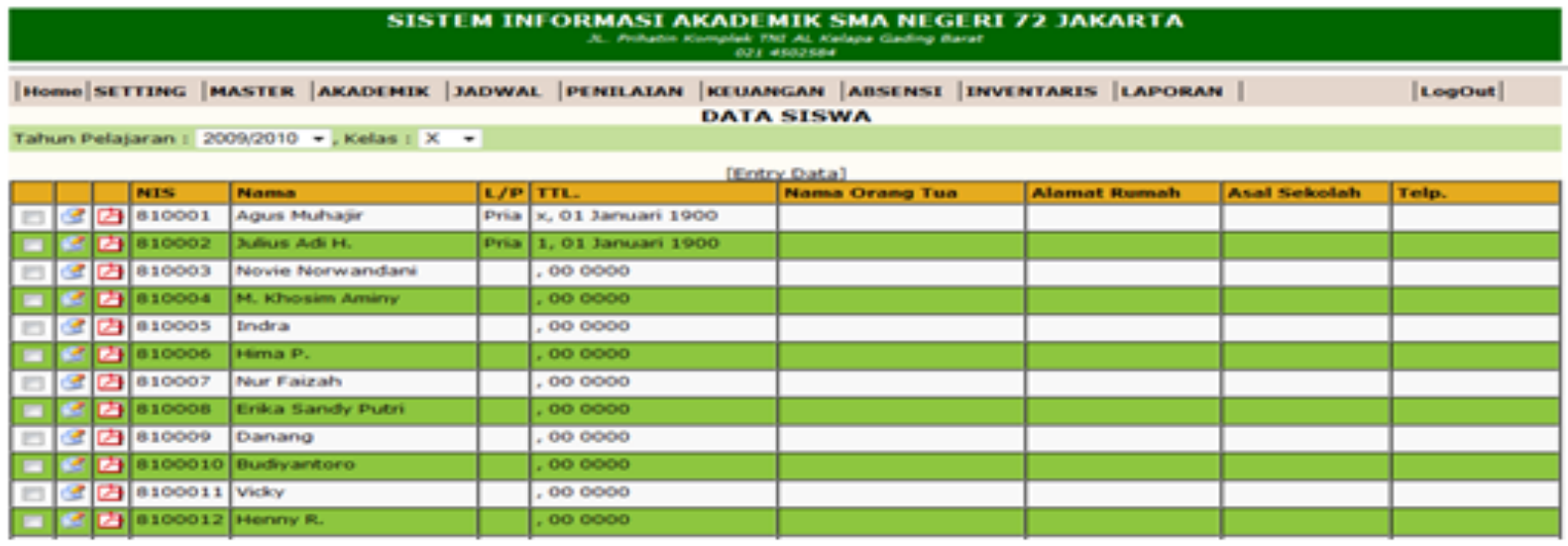

Gambar 4.5 Tampilan data siswa

\subsection{Spesifikasi Pendukung Web dan Pendukung Hardware, Software}

1. Minimum Kapasitas Hosting

Kapasitas hosting yang penulis dapatkan pada penggunaan web hosting ini sebesar space $50 \mathrm{MB}$, bw 2 GB.

2. Spesifikasi Hardware dan Software

Selain promosi melalui mesin pencari, dibutuhkan juga perangkat keras dan perangkat lunak.

3. Minimum Spesifikasi Hardware

Perangkat keras yang dimaksud disini adalah seperangkat alat atau elemen elektronik yang dapat membantu sistem yang diusulkan sehingga program yang diusulkan oleh penulis dapat bekerja dengan baik. Perangkat keras yang dibutuhkan dibagi atas dua bagian, yaitu perangkat keras untuk web server dan perangkat keras client.

Adapun perangkat keras minimal yang diperlukan oleh server adalah sebagai berikut:
a. Processor
: Pentium IV 2.4 Mhz
b. Memory Size (RAM) : 1 GB (DDRAM) 


$\begin{array}{ll}\text { c. Monitor } & \text { : SVGA Colour 15” } \\ \text { d. Harddisk } & : 80 \mathrm{~GB} \\ \text { e. Keyboard } & : 107 \text { Keys } \\ \text { f. Mouse } & : \text { Standard Mouse } \\ \text { g. Printer } & : \text { Deskjet }\end{array}$

Adapun perangkat keras minimal yang diperlukan oleh client. adalah sebagai berikut:
a. Processor
: Pentium II-400 Mhz
b. Memory Size (RAM): 256 MB (DDRAM)
c. Monitor : SVGA Colour 15”
d. Harddisk : $20 \mathrm{~GB}$
e. Keyboard : : 107 Keys
f. Mouse : Standard Mouse
g. Printer : Deskjet

4. Spesifikasi Software

Perangkat lunak adalah suatu rangkaian atau susunan instruksi yang harus benar dengan urutanurutan yang benar pula.Keberadaan perangkat lunak selalu menyertai perangkat keras yang ada. Perangkat lunak yang dibutuhkan dibagi atas dua bagian, yaitu perangkat lunak untuk web server dan perangkat lunak untuk client.

Adapun perangkat lunak minimal yang diperlukan untuk web server adalah sebagai berikut :
a. Sistem Operasi : Windows VISTA
b. Bahasa Program : PHP
c. Interpreter
: PHP4 Engine versi 5.2.4
d. Database Server : MySQL Server versi 5.2.4
e. Web Server : Apache versi 1.5.4 (for Windows)
f. Database Tools $\quad$ : PhpMyAdmin versi 2.11.1

Adapun perangkat lunak minimal yang diperlukan untuk client adalah sebagai berikut:

a. Sistem Operasi : Windows 9x/ ME / 2000/ XP

b. Browse : Mozila Firefox versi 5.5

\section{Kesimpulan}

Penerapan ketersediaan informasi akademik berbasis Website ini bertujuan untuk mengubah penyampaian pengelolaan dan penyimpanan data secara manual pada akademik SMA DKI Jakarta. Berikut ini beberapa kesimpulan yang dapat Penulis ambil, yaitu :

1. Beberapa keuntungan yang bisa diambil dengan penerapan perancangan Sistem Informasi berbasis web ini adalah dapat meminimalisir waktu, dan, tempat juga efektifitas dari administrasi tata usaha maupun guru dalam melakukan penilaian, dan manajemen penyampaian informasi.

2. Penyampaian informasi yang diberikan sekolah menjadi lebih baik dan lebih luas lagi, dan efektif karena dunia internet tidak mengenal batas wilayah, usia maupun waktu.

3. Sistem akademik pada SMA DKI Jakarta merupakan aplikasi sistem komputerisasi yang dibuat berbasis web dan memuat database pengolahan data penjualan alat-alat konstruksi secara terpusat sehingga memeilihara perangkat lunak (Software) dan perangkat keras (Hardware) dalam sistem terkomputerisasi secara benar dan berkala sehingga sistem ini dapat dipakai dalam waktu yang lama. dapat mengelolah database tersebut menjadi laporan dan Informasi yang dibutuhkan oleh kepala sekola SMA DKI Jakarta.

4. MySQL sebagai server database untuk aplikasi PHP. Kemudahannya dalam integrasi ke berbagai aplikasi web (terutama PHP) cukup membantu dalam pengembangan sistem Informasi akademik secara online 


\section{DaftarPustaka}

1. Ari Pambudi, Hurairah Pakaya. 2010. Analisis Dan Perancangan Sistem Informasi Kesiswaan Berbasis SMSGateway.Yogyakarta : Seminar Nasional Aplikasi Teknologi Informasi, 19 Juni 2010 : A.14

2. George R Tery. 2010. Denpasar: Seminar LPMP Cluster Development Coordinator Cluster 5 Bali Managing Contractor Program Management (MCPM) For The Australia- Indonesia Basic Education Program.2010

3. Hermawanto. 2009. Pengertian Web Engginering Diambil Dari http://kmrg.ITB.ac.id/blog/ 12 Desember 2009

4. John Burch, Gary Grunitsky.1986.Information Systems Theory and Practice Newyork : John Wiley 1986

5. Mohamad Sukarno, Membangun Website Dinamis Interaktif PHP-MySQL, Cetakan pertama eska Media, Bekasi 2006

6. Nataniel,Dyna Marisa, 2009. Sistem Informasi Akademik Berbasis Web SMP Negeri 4 Samarinda. Vol 4 No 2 Juli 2009

7. Soemarno. 2004. Perencanaan Analisis Dalam Perencanaan Lingkungan. Malang. 2004 
Prasetya et al / Edsence Vol. 1 No. 1, Juni 2019 pp. 9-18 